\title{
Effect of titanium oxide addition on magnesia refractories
}

\author{
Robert Kusiorowski ${ }^{1}$ (D)
}

Received: 8 March 2019 /Revised: 14 May 2020 / Accepted: 14 July 2020 / Published online: 20 July 2020

(C) The Author(s) 2020

\begin{abstract}
This work contains the results of investigations into the influence of titanium oxide $\left(\mathrm{TiO}_{2}\right)$ addition on the properties of refractory magnesia ceramics. The presented research involved adding titanium oxide in a classic way, i.e. directly to the ceramic mix. The conducted laboratory tests revealed a significant impact of this oxide on the properties of refractory materials. Addition of a small amount of $\mathrm{TiO}_{2}$ favoured the ceramic mix sintering whereas adding a bigger amount-more than $10 \mathrm{wt} \%$ resulted in the formation of refractories characterised by considerable porosity and low mechanical strength. Addition of this oxide also slightly improves the corrosive resistance of refractories.
\end{abstract}

Keywords Corrosion $\cdot \mathrm{MgO} \cdot \mathrm{TiO}_{2} \cdot$ Refractories

\section{Introduction}

Magnesia products are an important group of refractory materials, which have been produced for many years. Magnesia products owe their positive properties to their main chemical component, i.e. magnesium oxide (periclase, $\mathrm{MgO}$ ), which is characterised by extremely high refractoriness (melting point ca $2850^{\circ} \mathrm{C}$ ) $[1,2]$ and resistance to the corrosive attack of iron compounds as well as a relatively low hydration susceptibility and low thermal shock resistance [3]. Due to considerable contents of this oxide in the structure of refractory magnesia products, their chemical character is alkaline. Magnesia products are chemically resistant to the alkaline environment, alkaline slags, lime or cement, so they have been widely applied in many branches of industry [1-4].

Typical refractory magnesia products contain ca 98 wt $\%$ of magnesium oxide $\mathrm{MgO}$ [2-4], and the ratio of $\mathrm{MgO}$ to other components is responsible for the presence of final mineral phases in the refractory product. When their total content exceeds $2 \mathrm{wt} \%$, the product's refractoriness may be lowered due to the formation of phases with a lower melting point. In this case, the $\mathrm{C} / \mathrm{S}(\mathrm{CaO}$ to $\mathrm{SiO}_{2}$ ) ratio is extremely important as it determines the possibility of forming low-melting eutectics in the system $[2,5-7]$.

Robert Kusiorowski

r.kusiorowski@icimb.pl; robert.kusiorowski@interia.pl

$1 \quad$ Lukasiewicz Research Network, Institute of Ceramics and Building Materials, Refractory Materials Division in Gliwice, ul. Toszecka 99, 44-100 Gliwice, Poland
In recent years, the composition of magnesia products has been subjected to modifications as an addition of appropriate amounts to the $\mathrm{MgO}$ matrix improves the product's properties. The traditional solution involves using spinel-forming additives, including chrome ores. Although it is possible to obtain good properties of products from the $\mathrm{MgO}-\mathrm{Al}_{2} \mathrm{O}_{3}-\mathrm{Cr}_{2} \mathrm{O}_{3}-\mathrm{Fe}_{2} \mathrm{O}_{3}$ system, so modified materials pose a considerable ecological problem due to the presence of highly toxic chrome (VI) in materials after service [8]. The properties of magnesia products can among others be improved by adding zirconium oxide $[9,10]$ or tin oxide [11] to the system, which is indicated by the latest research.

Another possibility of modifying magnesia products is to add $\mathrm{TiO}_{2}$ to the ceramic mix. This oxide is applied in other industry branches, where it is among others used in the production of gas sensors in photovoltaic cells. It is also applied in the production of window glass or self-cleaning glass [12] and used in a traditional way as a pigment (titanium dioxide) for the production of paper, food, plastics, cosmetics, pharmaceuticals, porcelain, paints, and enamels. Titania has also been applied as an enamel colour stabilizer [12-14] and, in recent years, as a sintering agent in magnesia-alumina refractories and castables [15-17].

In the $\mathrm{MgO}-\mathrm{TiO}_{2}$ system [18], titanium oxide can form three compounds with magnesium oxide, namely magnesium metatitanate $\left(\mathrm{MgTiO}_{3}\right.$, geikielite), magnesium dititanate $\left(\mathrm{MgTi}_{2} \mathrm{O}_{5}\right.$, armalkolite $)$ and magnesium orthotitanate $\left(\mathrm{Mg}_{2} \mathrm{TiO}_{4}\right.$, qandilite). They are formed depending on mutual quantitative proportions of the initial oxides. All magnesium titanates are characterized by high refractoriness as their melting temperatures are higher than $1500^{\circ} \mathrm{C}$. There are, however, 
differences between particular magnesium titanates. Magnesium orthotitanate $\left(\mathrm{Mg}_{2} \mathrm{TiO}_{4}\right)$ has the highest melting point $\left(1756{ }^{\circ} \mathrm{C}\right)$ and seems to be the best solution from the point of view of refractory technology applications. The remaining two magnesium titanates (dititanate and metatitanate) are characterized by a considerably lower melting temperature, reaching 1620 or $1630^{\circ} \mathrm{C}$, respectively [18].

Adding a small amount of titanium oxide (less than $0.25 \mathrm{wt} \%$ ) to the system in the process of magnesia melting or sintering has a beneficial effect. As demonstrated by the authors [19-21], it can promote impurities diffusion, $\mathrm{MgO}$ crystallization and structural densification. The addition of titania has also improved sintering and single-stage synthesis of magnesium-aluminate spinel. Ghanbarnezhad and co-workers [22] analysed titania addition in terms of its role in the process of densification, aimed at achieving a better binding system for magnesia-based refractories. According to the authors, the optimum concentration of titania in spinel is $4 \mathrm{wt} \%$. An addition of titania also exerts a favourable impact on the structure of magnesia chrome refractory bricks [23] and silica refractories [24]. In the latter case, an addition of $0.5 \mathrm{wt} \%$ titania results in the formation of the highest amount of tridymite phase in the final product.

The influence of titania on refractory ceramic properties was also investigated by E. Rodriguez et al. [25]. The researchers determined the effect of titanium nanooxide on the physical properties of refractory magnesia ceramics. The conducted investigations revealed that the presence of titanium nanooxide promoted the formation of $\mathrm{Mg}_{2} \mathrm{TiO}_{4}$ and $\mathrm{CaTiO}_{3}$ titanates, which, in turn, improved the sintering process.

On the other hand, Mulange et al. [26] investigated the influence of titanium oxide addition on the properties of fired magnesia chrome shapes to be applied in copper or platinum converters. The obtained results indicate that materials with a $1-w t \%$ titania addition have better strength parameters than the remaining materials subjected to testing. As demonstrated by the authors, the addition of titanium oxide resulted in the formation of a spinel phase enriched with titanium in the product matrix, which enhanced its corrosion resistance.

The aim of the work was to determine the influence of titania addition on the properties of magnesia refractories as well as determining the obtained refractory materials' resistance to various corrosive agents that normally exist in the operating conditions of glass furnace regenerators, rotary cement kilns or ladles in steelmaking, where magnesia refractories are applied.

\section{Experimental}

\section{Raw materials}

In the investigations, the commercially available sintered magnesia clinker M30B (Magnesita Refractories, Brazil) and titanium oxide R001 (Tytanpol Police, Poland) were used.
Magnesium sulphite lye was used as a supporting material playing the role of anhydrous binder in the process of test sample forming. According to the producer's information, magnesia clinker was obtained in the double firing process (dead burned magnesia) of natural magnesite with a high content ( $\sim 98 \mathrm{wt} \%)$ of $\mathrm{MgO}$. The maximum particle size of magnesia grains was $5 \mathrm{~mm}$. Titania was delivered in the form of fine powder with the average particle size reaching $\sim 0.3 \mu \mathrm{m}$. The chemical compositions evaluated by X-ray fluorescence spectroscopy have been given in Table 1 .

\section{Ceramic sample preparation and sintering}

In order to evaluate the influence of titania addition on magnesia refractories, a number of refractory formulations were prepared. The first formulation did not contain titanium dioxide, while the remaining ten ceramic mixes had various titania concentrations, ranging from 1 to $30 \mathrm{wt} \%$. The raw materials were weighed according to the compositions shown in Table 2. The grain composition of the prepared ceramic mixes corresponded to Andreassen's cumulative curve: $P=0.1+0.9$ $(\mathrm{d} / \mathrm{D})^{0.37}$, where $P$ is the total share of grains (in wt $\%$ ) with dimensions not bigger than $\mathrm{d} \leq \mathrm{D}$; $\mathrm{d}$ is an arbitrarily chosen size of grains (in $\mathrm{mm}$ ), fulfilling the condition $0<\mathrm{d} \leq \mathrm{D}$; whereas $\mathrm{D}$ is the upper limit of the mix granulation (in $\mathrm{mm}$ ).

To prepare a formable green body, the weighed raw materials were thoroughly mixed with a 3.5 -wt $\%$ additive of lignosulphonate binder. The ceramic mixes were prepared in a laboratory electric mixer in the following order: first, an appropriate amount of coarse magnesia clinker; next, the binder and, finally, the dust fraction of raw materials were added. After mechanical mixing, the resulting ceramic mixes were pressed into cylindrical samples $(50 \mathrm{~mm}$ in diameter and $50 \mathrm{~mm}$ in height) at a pressure of $120 \mathrm{MPa}$ and ventilation pressure of $60 \mathrm{MPa}$. Next, the green samples were dried in natural conditions at room temperature and in a laboratory dryer at $120^{\circ} \mathrm{C}$ for $4 \mathrm{~h}$. The dried samples were sintered in a high-temperature laboratory gas furnace at $1600{ }^{\circ} \mathrm{C}$, for a soaking time of $4 \mathrm{~h}$. Finally, the refractory samples were naturally cooled in a furnace until they reached room temperature.

\section{Properties of the obtained refractories and testing methods}

After firing, basic physical and thermomechanical properties of the obtained $\mathrm{MgO}-\mathrm{TiO}_{2}$ refractories were investigated. The following were determined: linear shrinkage, open porosity, apparent density, compression strength and gaseous permeability (according to PN-EN 993 standards). The obtained refractories were also subjected to thermal shock resistance tests, which involved cyclical heating in a furnace $\left(950{ }^{\circ} \mathrm{C} /\right.$ $25 \mathrm{~min}$ ) and cooling the samples in water ( $3 \mathrm{~min})$ until they 
Table 1 Chemical composition of raw materials

Raw material Oxide composition (wt\%)

\begin{tabular}{lllllllllll} 
& $\mathrm{MgO}$ & $\mathrm{TiO}_{2}$ & $\mathrm{SiO}_{2}$ & $\mathrm{Al}_{2} \mathrm{O}_{3}$ & $\mathrm{Fe}_{2} \mathrm{O}_{3}$ & $\mathrm{CaO}$ & $\mathrm{K}_{2} \mathrm{O}$ & $\mathrm{Na}_{2} \mathrm{O}$ & $\mathrm{MnO}$ & $\mathrm{LOI}$ \\
\hline $\mathrm{MgO}$ & 97.67 & 0.02 & 0.44 & 0.27 & 0.43 & 0.87 & $<0.01$ & 0.02 & 0.14 & 0.25 \\
$\mathrm{TiO}_{2}$ & 0.09 & 97.40 & 0.15 & 0.99 & $<0.01$ & 0.02 & 0.01 & $<0.01$ & $<0.01$ & 1.20 \\
\hline
\end{tabular}

lost $20 \%$ of their initial mass. Each parameter was determined for a minimum of three samples; the final result was the average value of partial results. The obtained refractory materials were also subjected to porosimetric tests. The AUTOPORE 9500 mercury porosimeter, produced by Micromeritics, which was used for this purpose, enabled testing the porosity and grain size distribution within a range of 0.006 to $450 \mu \mathrm{m}$.

Corrosion resistance was tested by the crucible method for selected samples obtained at an earlier stage. Holes of $20 \mathrm{~mm}$ in diameter and ca $20 \mathrm{~mm}$ in depth were cut out in the refractory samples; $7 \mathrm{~g}$ of the corrosive agent was placed in each hole and manually pressed. Three corrosive agents with chemical compositions presented in Table 3 were prepared. In the corrosion test, the use of the "glassy" agent (agent number 1) in the composition was aimed at recreating conditions in glass furnace regenerators; the "steel" agent (agent number 2) was chosen to reproduce metallurgical slag, whereas the "cementitious" agent (agent number 3) was selected to recreate the conditions in a cement furnace - taking into consideration both the components of cement clinker and components from the furnace atmosphere (presence of sulphur compounds). Raw materials needed to prepare corrosive sets were initially dried $\left(120^{\circ} \mathrm{C} / 4 \mathrm{~h}\right)$ and, next, weighed in appropriate amounts. The corrosive sets were homogenized in a fine powder mill. In the case of agent number 2, the corrosive agent was first synthesized at $1300{ }^{\circ} \mathrm{C}$ for $4 \mathrm{~h}$. Samples with the corrosive agent were fired in a furnace at $1400^{\circ} \mathrm{C} / 6 \mathrm{~h}$ (corrosive agent number 1), $1500{ }^{\circ} \mathrm{C} / 4 \mathrm{~h}$ (corrosive agent number 2) or $1500{ }^{\circ} \mathrm{C} / 10 \mathrm{~h}$ (corrosive agent number 3). After being cooled, the samples were cut along the cylinder's height. The cut fragments were wiped with a slightly damp cloth to remove dust and expose the corroded surface subjected to planimetrization. The percentage of uncorroded sample surface was assumed to be the measure of the material's corrosive resistance, i.e. the higher the value obtained by planimetering, the higher corrosive resistance the material had.
The raw materials' chemical composition was determined by X-ray fluorescence spectroscopy (PANalitycal Magix PW2424 spectrometer), while the phase composition of raw materials and of the obtained refractory materials was determined by the X-ray diffraction technique (XRD), using a PANalytical X'pert Pro diffractometer $(\mathrm{CuK} \alpha$ radiation, Ni filter, $40 \mathrm{kV}, 30 \mathrm{~mA}$, X'Celerator detector). The microstructure of selected refractory samples obtained was observed in a scanning electron microscope (Mira III, Tescan) equipped with an EDS (Oxford Instruments). The liquid phase contents in magnesia-titania refractories at high temperatures were calculated using the "Equilib" module of the "FactSage" software (version 6.4), whereas the liquid phase viscosity at high temperature was determined by means of the "Viscosity" module of the same software. All calculations were performed for the $1200-1700^{\circ} \mathrm{C}$ temperature range and the total pressure of $1 \mathrm{~atm}$.

\section{Results and discussion}

\section{Raw materials characteristics}

The most important parameter in the composition of magnesia clinker is the content of silica, as it influences the $\mathrm{C} / \mathrm{S}(\mathrm{CaO}$ to $\mathrm{SiO}_{2}$ ) ratio, which, in consequence, affects the formation of phases co-existing with periclase $(\mathrm{MgO})$ in basic refractories $[2,4]$. It is commonly known that properties of magnesia refractory bricks are influenced by the type and amount of the accompanying oxides and the resulting phase formation, depending on the $\mathrm{C} / \mathrm{S}$ ratio. When $\mathrm{C} / \mathrm{S}$ molar ratio is below 2 in the $\mathrm{MgO}-\mathrm{CaO}-\mathrm{SiO}_{2}$ system, silica reacts with $\mathrm{CaO}$ and $\mathrm{MgO}$ and low-melting phases, such as monticellite (CMS, $\left.\mathrm{CaMgSiO}_{4}\right)$ or merwinite $\left(\mathrm{C}_{3} \mathrm{MS}_{2} ; \mathrm{Ca}_{3} \mathrm{Mg}\left(\mathrm{SiO}_{4}\right)_{2}\right)$, can be formed $[2,27]$.

Table 2 Composition of the refractory formulations

\begin{tabular}{|c|c|c|c|c|c|c|c|c|c|c|c|}
\hline \multirow[t]{2}{*}{ Composition (wt\%) } & \multicolumn{11}{|c|}{ Refractory formulations } \\
\hline & T0 & $\mathrm{T} 1$ & $\mathrm{~T} 2$ & $\mathrm{~T} 3$ & $\mathrm{~T} 5$ & $\mathrm{~T} 8$ & $\mathrm{~T} 10$ & $\mathrm{~T} 15$ & $\mathrm{~T} 20$ & $\mathrm{~T} 25$ & $\mathrm{~T} 30$ \\
\hline Magnesia clinker & 100 & 99 & 98 & 97 & 95 & 92 & 90 & 85 & 80 & 75 & 70 \\
\hline Titania & - & 1 & 2 & 3 & 5 & 8 & 10 & 15 & 20 & 25 & 30 \\
\hline
\end{tabular}


Table 3 Compositions of corrosive agents

Composition (wt\%)

\begin{tabular}{|c|c|c|c|c|c|c|c|}
\hline \multirow[t]{2}{*}{ Corrosive agent no. 1} & Silica & Sodium carbonate & Sodium sulphate & Dolomite & Alumina & Manganese oxide & \\
\hline & 30 & 36 & 20 & 10 & 2 & 2 & \\
\hline \multirow[t]{2}{*}{ Corrosive agent no. 2} & Silica & Alumina & Iron(III) oxide & Calcia & Magnesia & Manganese oxide & Titania \\
\hline & 24.5 & 20.8 & 30.9 & 22.1 & 0.7 & 0.1 & 0.9 \\
\hline \multirow[t]{2}{*}{ Corrosive agent no. 3} & \multicolumn{2}{|c|}{ Ordinary Portland cement } & \multicolumn{2}{|l|}{ Potassium sulphate } & \multicolumn{3}{|l|}{ Graphite } \\
\hline & \multicolumn{2}{|l|}{45} & \multicolumn{2}{|l|}{50} & \multicolumn{3}{|l|}{5} \\
\hline
\end{tabular}

The obtained chemical composition results demonstrate that the $\mathrm{C} / \mathrm{S}$ ratio for the clinker used is nearly 2 , which indicates that the clinker itself, apart from periclase, should be expected to contain mainly dicalcium silicate $\mathrm{C}_{2} \mathrm{~S}(2 \mathrm{CaO}$. $\mathrm{SiO}_{2}$ ) (Table 1). Due to its low content and dispersion in the clinker, only a trace of this phase was identified by the XRD method (Fig. 1). Low-melting phases, such as monticellite and merwinite, were not found. Chemical composition investigations confirmed the high content of titania in the raw materials used, exceeding 97 wt\% (Table 1). The main mineral component was rutile with a small admixture of $\mathrm{TiO}_{2}$, in the form of anatase (Fig. 1).

\section{Properties of $\mathrm{MgO}_{-} \mathrm{TiO}_{2}$ refractories obtained}

A comparison of the phase compositions of the obtained refractory materials has been presented in Fig. 2. The increasing concentration of titanium oxide in the green ceramic mixes resulted in changes in X-ray diffraction patterns. Due to the reaction of magnesium oxide with titanium oxide, a gradual decrease in the intensity of periclase reflections was observed. However, there was a noticeable increase in the intensity of reflections from dimagnesium titanate (qandilite, $\mathrm{Mg}_{2} \mathrm{TiO}_{4}$ ). Weak reflections of perovskite $\left(\mathrm{CaTiO}_{3}\right)$ were also identified for all the samples containing titanium oxide. It was formed as a result of dicalcium silicate conversion with titania. The remaining silica reacted with magnesium oxide to form forsterite $\left(\mathrm{Mg}_{2} \mathrm{SiO}_{4}\right)$, the traces of which were also identified in XRD patterns. The presence of perovskite calcium titanate and forsterite is beneficial, because both compounds have high melting points, $\sim 1990{ }^{\circ} \mathrm{C}$ [28] and $\sim 1890{ }^{\circ} \mathrm{C}$ [29], respectively.

The results of all determined physical properties of refractories obtained by incorporating various amounts of titania $\left(\mathrm{TiO}_{2}\right)$ in magnesia materials are presented in three subsequent figures (Figs. 3, 4, 5).

An analysis of the determined parameters' results allows concluding that titanium oxide has a significant influence on the properties of magnesia refractories. There is a limit value of titania added to a ceramic mix which determines the physical properties of refractory materials from the $\mathrm{MgO}-\mathrm{TiO}_{2}$ system. An addition of a few percent of titania improves the obtained materials' parameters, but when its amount exceeds $8 \mathrm{wt} \%$, the refractory properties are observed to considerably deteriorate. It is consistent with the test results presented by Rodríguez et al. [25], where a 5-wt\% addition of $\mathrm{TiO}_{2}$ in the form of nanopowder enabled the researchers to obtain products with maximally enhanced physical properties. The 5-wt\%
Fig. 1 Phase composition of raw materials determined by XRD

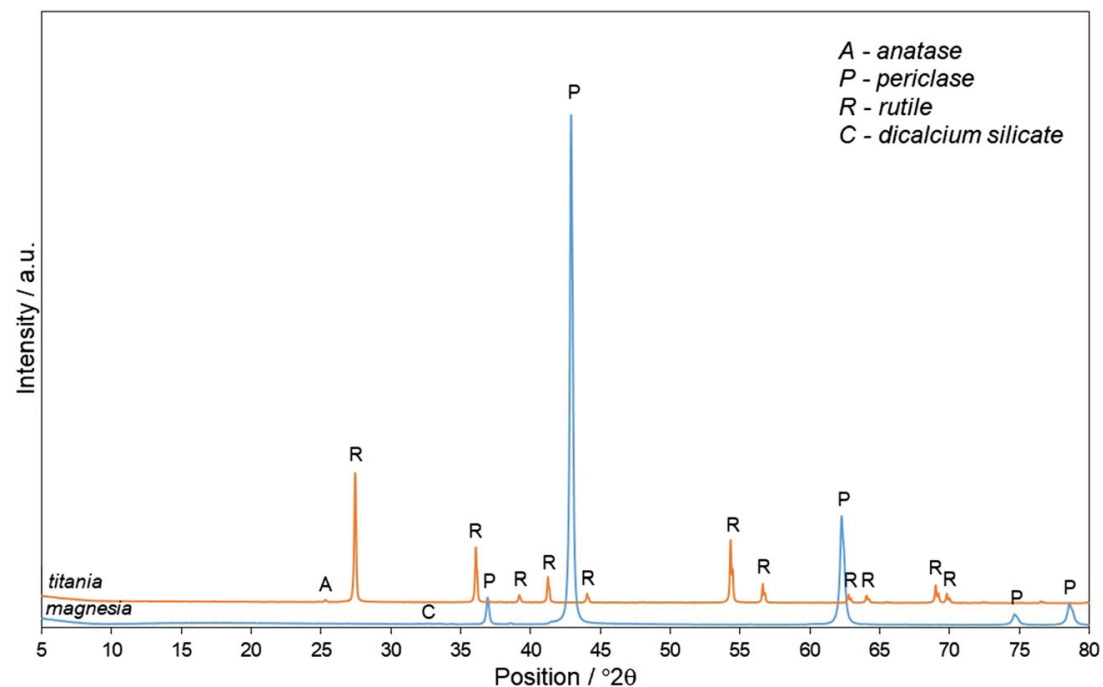




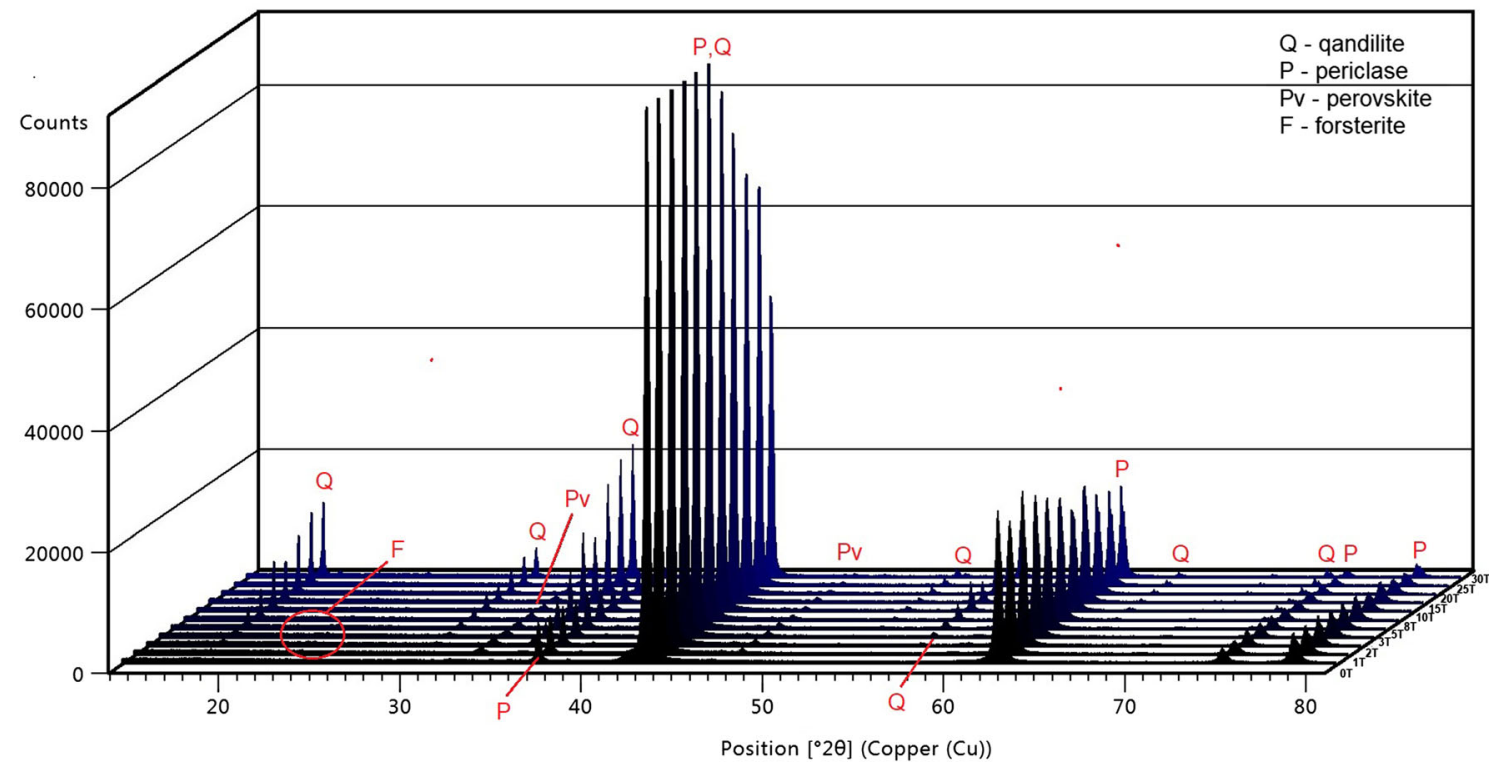

Fig. 2 Comparison of XRD patterns coming from the obtained magnesia-titania refractories

addition was found to result in the highest material density and compressive strength.

All the obtained refractory materials were characterized by relatively low total shrinkage (Fig. 5). Maximum linear changes of the samples reached ca $1 \%$. It should be noted that the materials' shrinkage gradually increased until the level of titania addition reached approximately $8 \%$ - further increase of this oxide content in the mix considerably reduced the shrinkage, and after adding the maximum assumed content of $\mathrm{TiO}_{2}$ (i.e. $30 \mathrm{wt} \%$ ), the material was even found to slightly bulge (negative value of total shrinkage).

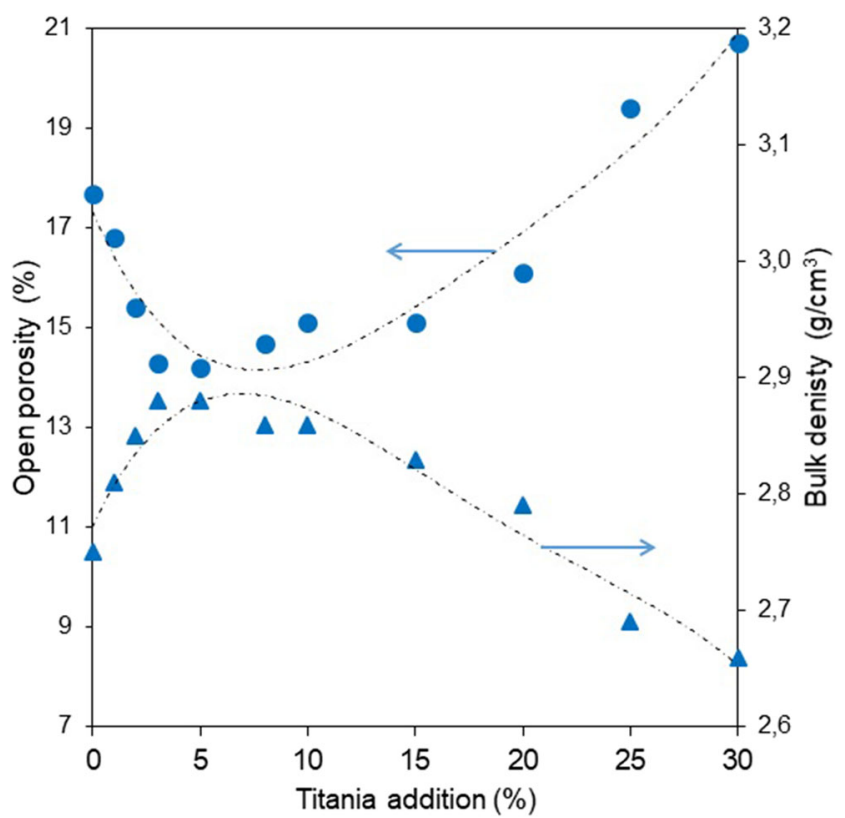

Fig. 3 Bulk density (triangle) and open porosity (circle) values as a function of titania additions
The addition of a few percent of titania improved the parameters of refractories as their bulk density was observed to increase (from $2.75 \mathrm{~g} / \mathrm{cm}^{3}$ for the reference sample to ca 2.85 $2.88 \mathrm{~g} / \mathrm{cm}^{3}$ for samples T5 and T8) (Fig. 3), which can be linked to the sintering process intensification and microstructure densification. This phenomenon leads to a significant decrease of material's open porosity (from ca $18 \%$ to ca $14 \%$ ) and a considerable increase of mechanical strength of refractories from the $\mathrm{MgO}-\mathrm{TiO}_{2}$ system. The addition of ca $5 \mathrm{wt} \% \mathrm{TiO}_{2}$ to the ceramic mix resulted in an increase of strength by approximately $20 \%$, from 54 to $66 \mathrm{MPa}$ (Fig. 4).

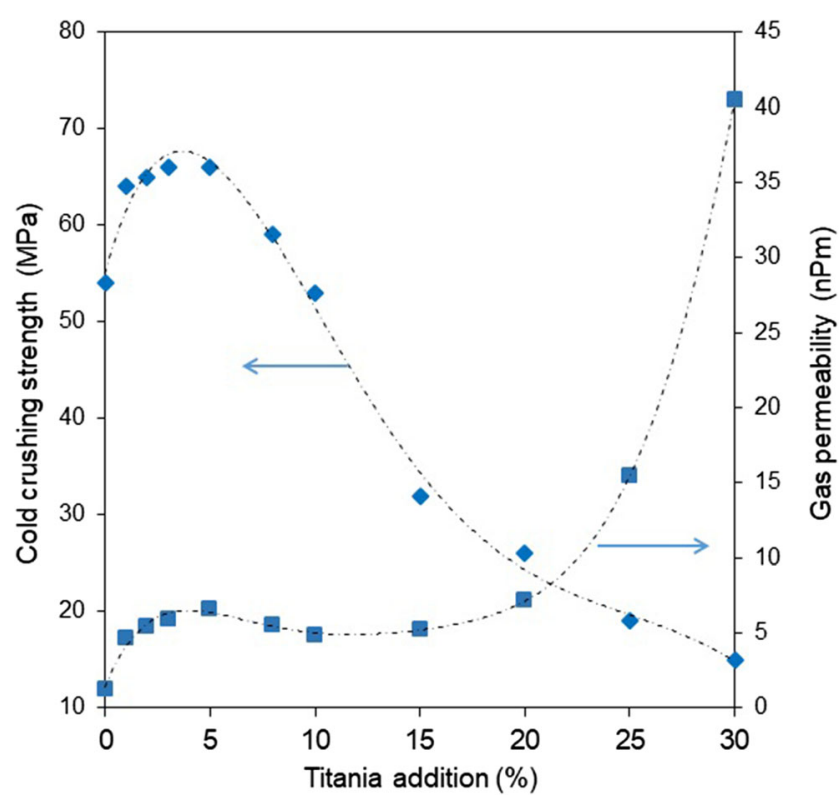

Fig. 4 Cold crushing strength (diamond) and gas permeability (square) values as a function of titania additions 


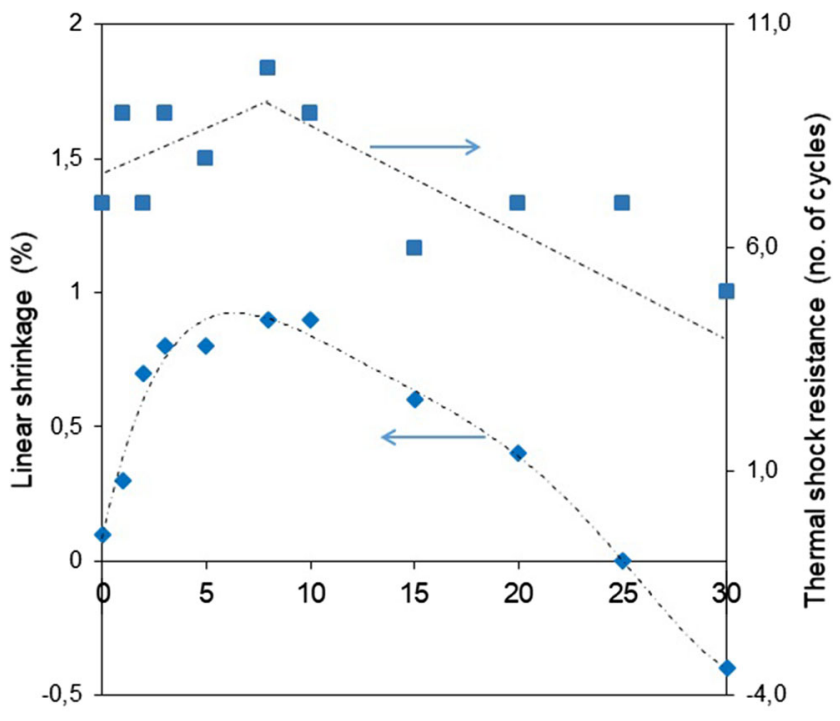

Titania addition (\%)

Fig. 5 Linear shrinkage (diamond) and thermal shock resistance (square) values as a function of titania additions

The above findings can be easily explained by the influence of titanium oxide on the sintering process and the results of thermodynamic calculations. The amount of liquid phase forecast in thermodynamic calculations in the FactSage software gradually increased with an increase of titania addition and temperature, as shown in Fig. 6. For samples with a lower titania concentration, the amount of the liquid phase formed at firing temperatures is relatively low-5 to $10 \mathrm{wt} \%$. With higher titania concentrations and firing temperatures, the amount of liquid phase rapidly increases, reaching the level of up to $\sim 30 \mathrm{wt} \%$ for the highest calculated temperature and the concentration of titania exceeding $15 \mathrm{wt} \%$. Another very important factor of the liquid phase is viscosity. The calculated liquid phase viscosity continuously decreased with temperature (Fig. 7). The viscosity of the liquid phase in samples with titania at the considered temperature was practically the same for all the tested samples, changing only to a slight degree. In the considered system, lower viscosity is observed in the case of samples having a lower concentration of titania, especially at lower calculated temperatures, which is directly connected with the chemical composition of titania used in the study (Table 1). As the concentration of titania in the green body increases, the concentration of alumina is expected to reach a relatively high level, which results in an increase of the liquid phase viscosity. It is worth noting that a low concentration of low-melting phases has a great impact on the sintering properties and the slag resistance of magnesia refractories $[2$, 15].

A further increase of $\mathrm{TiO}_{2}$ content (more than $8 \mathrm{wt} \%$ ) in the mix contributed to significant deterioration of the refractory materials, as apparent density was found to decrease (below $2.7 \mathrm{~g} / \mathrm{cm}^{3}$ ) or open porosity was observed to increase (over
$20 \%$ - its value was notably higher in relation to the reference value determined for the reference material without $\mathrm{TiO}_{2}$ addition. Increasing the content of titania had a strong influence on mechanical strength. A $30 \%$ addition of $\mathrm{TiO}_{2}$ was observed to cause a drop in strength from the level of ca $66 \mathrm{MPa}$ (for mixes T3 and T5) to merely $15 \mathrm{MPa}$ (for T30). The effect can be correlated with considerable loosening of the material's structure as a result of the reaction of components characterized by high real density (ca $3.8 \mathrm{~g} / \mathrm{cm}^{3}$ in the case of periclase and ca $4.2 \mathrm{~g} / \mathrm{cm}^{3}$ in the case of rutile [2]) leading to the formation of magnesium orthotitanate (qandilite, $\mathrm{Mg}_{2} \mathrm{TiO}_{4}$ ), the density of which reaches ca $3.5 \mathrm{~g} /$ $\mathrm{cm}^{3}$ [2]. It can be also related to the intense sintering process, which entails an increased volume of the system - the bigger amounts of $\mathrm{TiO}_{2}$ will react, the more the system volume will increase. When the amount of $\mathrm{TiO}_{2}$ in the mix was large enough (as in the case of T30 mix), it was observed to bulge.

Adding a few percent of $\mathrm{TiO}_{2}$ to the ceramic mix also increased the materials' gaseous permeability (Fig. 4). The gaseous permeability of all refractories containing up to $15 \mathrm{wt} \%$ of $\mathrm{TiO}_{2}$ reached ca 5 to $6 \mathrm{nPm}$. The microstructure loosening due to bulging caused a considerable increase in the materials' gaseous permeability - in the case of mix T30, this value rose more than 30 times, from ca 1.2 to ca $40 \mathrm{nPm}$.

$\mathrm{TiO}_{2}$ addition also had a considerable impact on the materials' thermal shock resistance (Fig. 5). Materials with a fewpercent content of $\mathrm{TiO}_{2}$ were characterized by thermal shock resistance (TSR; cycles $950^{\circ} \mathrm{C}$ ) on the level of 8-10 cycles, whereas the values of TSR for materials with higher contents of $\mathrm{TiO}_{2}$ (more than $10 \%$ ) were lower by a few cycles.

Porosimetric investigations (Table 4) were conducted for selected refractories with titania contents of up to $10 \mathrm{wt} \%$, in which the adverse effect related to the formation of qandilite was not so significant. The results have demonstrated that a few-percent addition contributes to the formation of larger pores in materials (bigger volumetric median of pore diameter or average pore diameter) with a simultaneous two-three-fold decrease of the content of the smallest pores having dimensions $<1 \mu \mathrm{m}$. A significant increase of permeability is directly correlated with a drop of tortuosity coefficient, which indicates a higher content of tubular (pass-through) pores in the material.

The above was confirmed by SEM observations. In comparison with T0 sample, without any titania addition (Fig. 8a), a clearly visible difference in microstructure was observed in the case of the titania-containing material (Fig. 8b-f). Titanium oxide reacts mainly with fine magnesia grains, which in the sintering process leads to its build-up and formation of an envelope on bigger medium-sized grains. With a higher concentration of titania, the coarse grains of periclase also react, and a heavily sintered phase of dimagnesium titanate is observed to form in refractories (Figs. $8 \mathrm{f}$ and $9 \mathrm{c}$ ). This is due to the appearance of a liquid phase in the presence of $\mathrm{TiO}_{2}$ at an 
Fig. 6 Thermodynamic simulations for the liquid phase contents in the considered magnesia-titania refractories

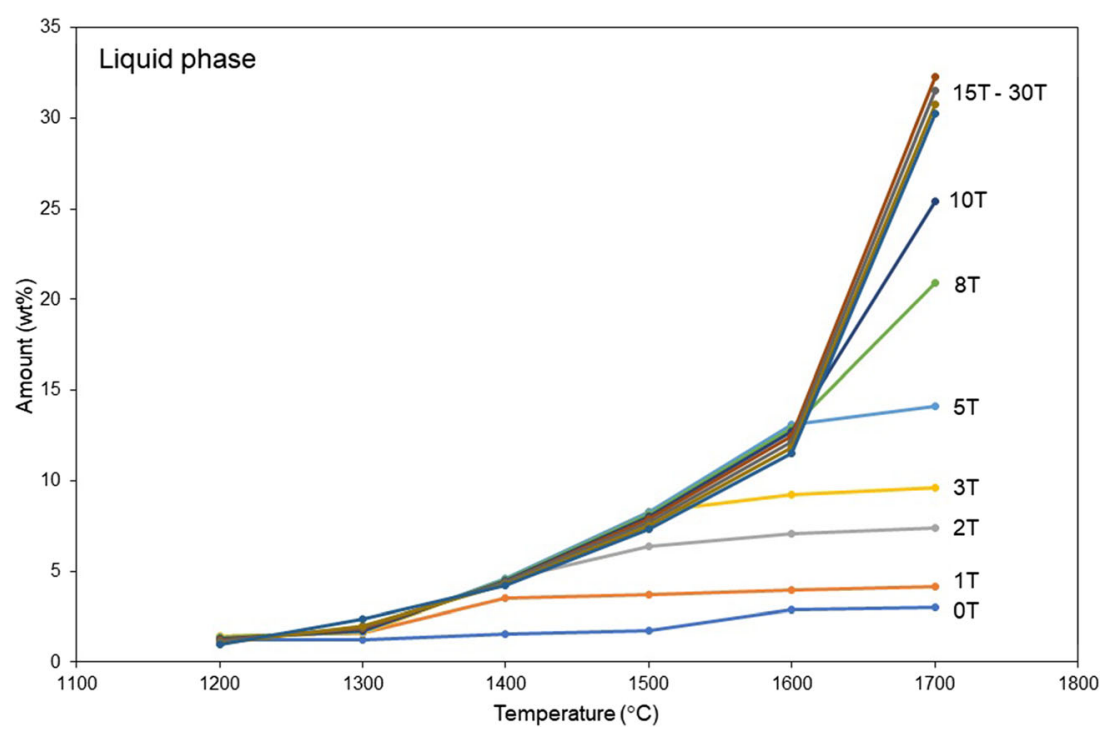

early firing stage. The early presence of the liquid phase and its greater amount in materials with a higher $\mathrm{TiO}_{2}$ content caused deep changes in the microstructure. Intensive sintering of fine grains led to the refractory matrix losing its granular character and contributed to the simultaneous formation of pass-through pores with a considerable diameter (Fig. 8f). As a result, the pores become wider and longer. In consequence, tortuosity decreased. Due to better and easier gas flow conditions, the addition of a bigger amount of titania was observed to increase gas permeability. This is consistent with the results presented by Szczerba [1], who observed a nearly three-fold increase in gas permeability of fired magnesiaspinel materials due to a change in the structure of pores.

Figure 9 shows the microstructure of a polished section of sintered magnesia with an addition of titania at a higher magnification $(2000 \times)$. This microstructure consists of rounded grains of a lighter contrast material in the intergranular region.
An EDS analysis (Table 5) confirmed that $\mathrm{MgO}$ and $\mathrm{TiO}_{2}$ reacted during the sintering process to form $\mathrm{Mg}_{2} \mathrm{TiO}_{4}$. In addition, calcium compounds contained in the sintered raw magnesia material (mainly in the form of calcium disilicate $\mathrm{Ca}_{2} \mathrm{SiO}_{4}$ ) reacted with titania and formed calcium titanate $\mathrm{CaTiO}_{3}$. As a result of this reaction, the $\mathrm{C} / \mathrm{S}$ ratio changed and the system was calcium impoverished, while silica could react with magnesia to form magnesium silicate $\left(\mathrm{Mg}_{2} \mathrm{SiO}_{4}\right.$, forsterite) characterized by a high melting temperature. Its traces were identified by XRD measurements (Fig. 2).

\section{Corrosion study}

An example of the appearance of refractory materials subjected to a corrosion test, with the corrosion area marked, has been presented in Fig. 10, whereas the results and comparison of
Fig. 7 Viscosity of liquid phase in the selected considering magnesia-titania refractories

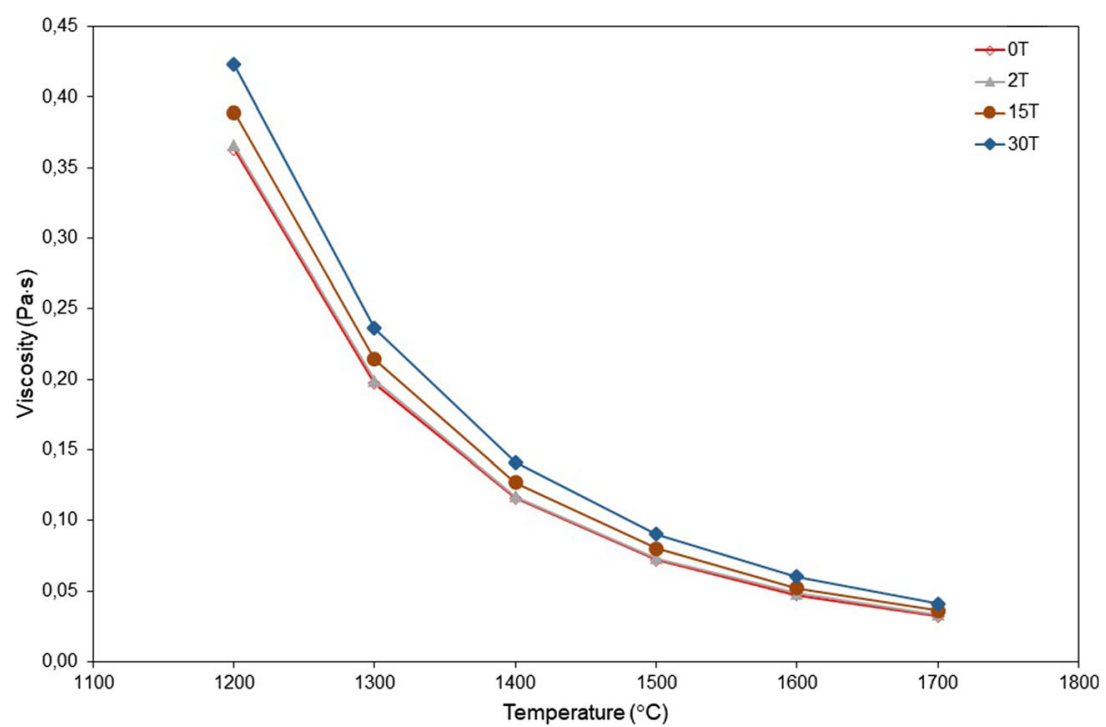


Table 4 Porosimetry test results of selected samples

\begin{tabular}{|c|c|c|c|c|c|c|c|}
\hline \multirow[t]{2}{*}{ Parameter } & \multicolumn{7}{|c|}{ Sample } \\
\hline & T0 & $\mathrm{T} 1$ & $\mathrm{~T} 2$ & $\mathrm{~T} 3$ & T5 & $\mathrm{T} 8$ & $\mathrm{~T} 10$ \\
\hline Total pore area $\left(\mathrm{m}^{2} / \mathrm{g}\right)$ & 0.094 & 0.040 & 0.032 & 0.026 & 0.038 & 0.046 & 0.047 \\
\hline Median pore diameter $(\mathrm{vol})(\mu \mathrm{m})$ & 4.96 & 12.22 & 16.7 & 18.87 & 17.76 & 15.13 & 12.24 \\
\hline Average pore diameter $(\mu \mathrm{m})$ & 2.69 & 5.71 & 6.37 & 7.42 & 5.19 & 4.42 & 4.49 \\
\hline Porosity (\%) & 18.1 & 16.7 & 15.2 & 14.2 & 14.6 & 15.0 & 15.5 \\
\hline Permeability (mdarcy) & 5.97 & 22.19 & 39.53 & 46.97 & 48.67 & 33.56 & 19.66 \\
\hline Content of pores $\varnothing<90 \mu \mathrm{m}(\%)$ & 97.12 & 96.66 & 95.63 & 95.48 & 94.13 & 95.70 & 95.72 \\
\hline Content of pores $\varnothing<30 \mu \mathrm{m}(\%)$ & 96.54 & 94.33 & 85.62 & 77.00 & 78.94 & 88.83 & 94.57 \\
\hline Content of pores $\varnothing<10 \mu \mathrm{m}(\%)$ & 88.21 & 36.77 & 21.85 & 14.56 & 18.27 & 23.47 & 33.00 \\
\hline Content of pores $\varnothing<1 \mu \mathrm{m}(\%)$ & 6.35 & 2.73 & 2.43 & 2.74 & 2.80 & 3.68 & 3.54 \\
\hline Tortuosity & 13.40 & 8.95 & 7.79 & 7.81 & 7.78 & 8.00 & 9.39 \\
\hline
\end{tabular}

selected refractories' resistance to the attack of corrosive agents have been shown in Fig. 11.

It was found that the refractories obtained were not resistant to corrosive agent number 1 , as after the test, white sediment was found on the surface and inside the samples. Due to the corrosive agent's penetration throughout the material and the appearance of white sediment - most probably carbonate compounds formed as a result of secondary carbonization- these samples were not planimetered in further tests. The effect of deep penetration by the corrosive agent most probably resulted from the considerable amount of slag in the form of a liquid phase characterized by low viscosity, caused by a high share of sodium compounds in the composition.

On the other hand, a macroscopic inspection of the materials subjected to corrosive tests conducted for the remaining two agents (numbers 2 and 3) revealed clearly a corrosive
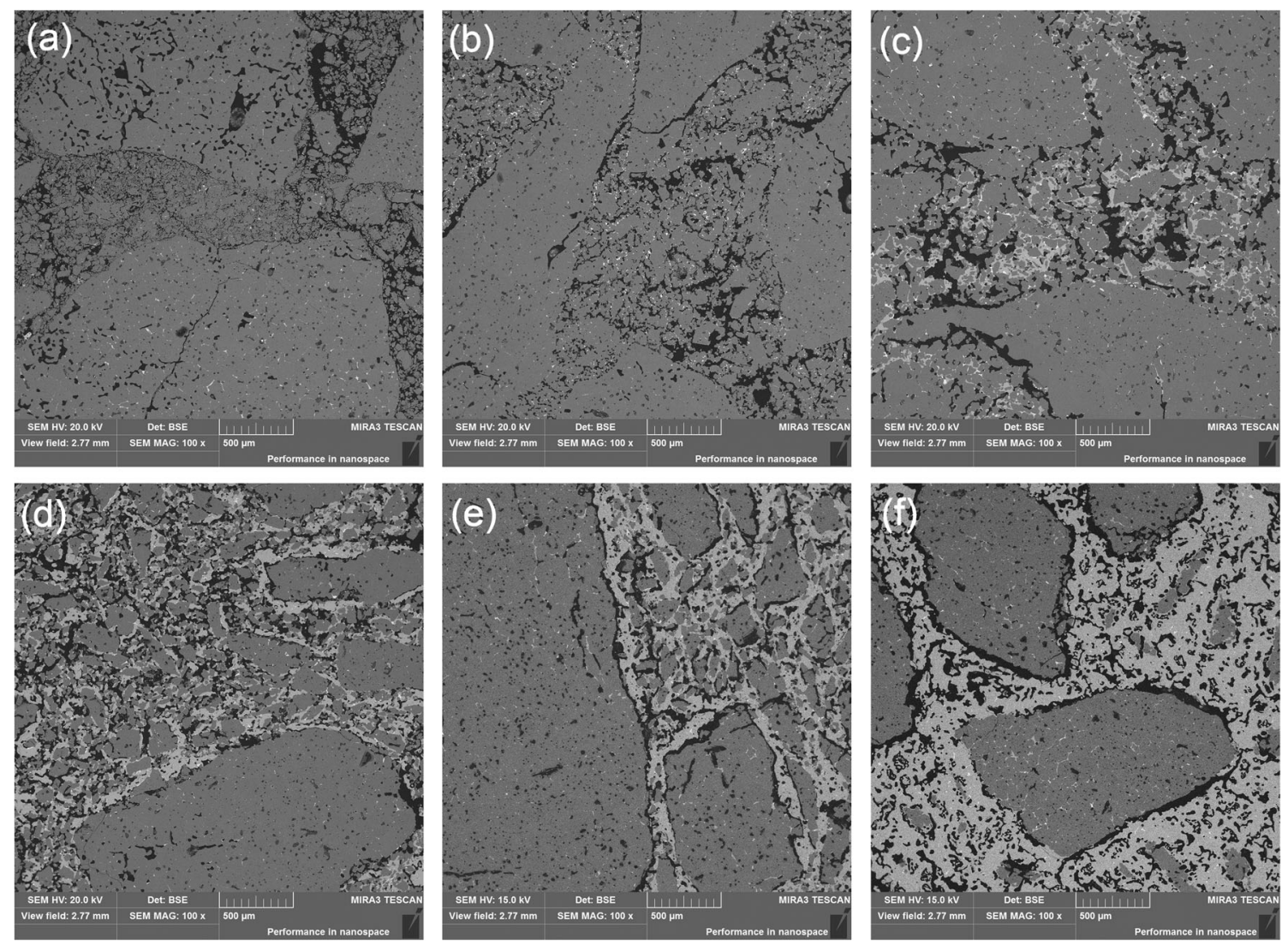

Fig. 8 SEM images of selected materials from the $\mathrm{MgO}-\mathrm{TiO}_{2}$ system: sample $\mathrm{T} 0$ (a), sample $\mathrm{T} 1$ (b), sample $\mathrm{T} 5$ (c), sample $\mathrm{T} 10$ (d), sample $\mathrm{T} 20$ (e) and sample T30 (f) 

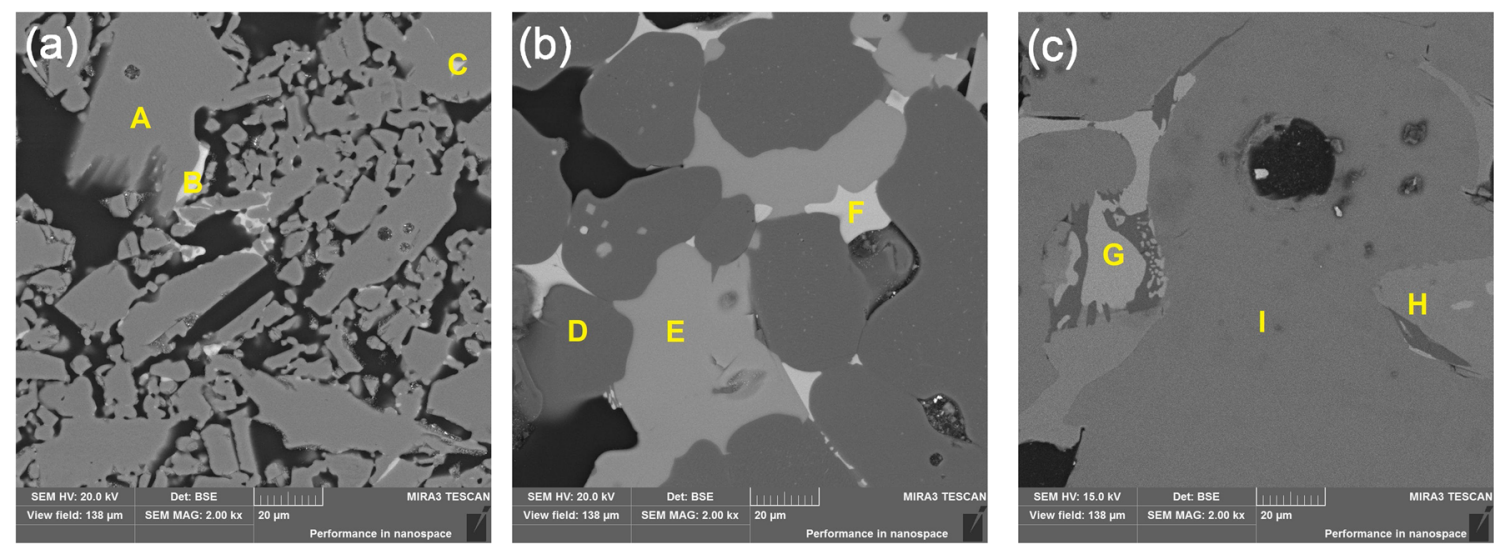

Fig. 9 SEM images at higher magnification of selected obtained refractory samples: T0 (a), T5 (b) and T30 (c) with marked place of chemical analysis by EDS analysis (Table 5 )

zone in the tested refractories. It can be seen that $\mathrm{TiO}_{2}$ addition had a slight but beneficial influence on the obtained refractory materials' resistance to these corrosive agents. Macroscopically, the zone of penetration by particular corrosive mixes was reduced.

An attempt to quantitatively determine the enhancement of corrosive resistance achieved by adding titanium oxide on the basis of corrosion area planimetrization did not show any correlation between $\mathrm{TiO}_{2}$ added to the mix in the amount of maximum $8 \mathrm{wt} \%$. A comparison of the obtained results (Fig. 11) merely indicates that the addition of $\mathrm{TiO}_{2}$ slightly improved the material's resistance in relation to the material without it, as all the materials with titanium oxide were characterized by higher resistance (by a few percent) compared to the reference material. In the case of corrosive agent number 3 , which was rich in $\mathrm{Ca}$, calcium titanate $\mathrm{CaTiO}_{3}$ was formed in the corrosive agent-material contact area, which hindered further corrosion due to the high melting point [2], whereas in the case of agent number 2, rich in $\mathrm{Fe}$ compounds, the enhancement of corrosion resistance results from the fact that in the contact area of the refractory material and molten slag, rich in iron oxides, the latter can react with $\mathrm{MgO}$, forming magnesioferrite $\left(\mathrm{MgFe}_{2} \mathrm{O}_{4}\right)$, which, in turn, forms the homogenous phase of the component oxides' solid solution with magnesium orthotitanate $\left(\mathrm{Mg}_{2} \mathrm{TiO}_{4}\right)$, thus preventing further penetration of the melt/slag inside the refractories [21,30].

\section{Conclusions}

The conducted investigations and their results allow concluding as follows:

- A small addition of titania (maximum of a few percent) has a positive effect on the process of refractory sintering, as linear shrinkage and apparent density were found to increase, and, at the same time, open porosity was observed to decrease.

- A small addition of titania influences the mechanical strength of refractory materials, causing its increase compared to materials without $\mathrm{TiO}_{2}$; thermal shock resistance was also observed to increase.

Table 5 Chemical and phase composition determined by EDS of points presented on Fig. 9

\begin{tabular}{|c|c|c|c|c|c|c|c|}
\hline \multirow[t]{2}{*}{ Point no. } & \multicolumn{6}{|c|}{ Element (at\%) } & \multirow[t]{2}{*}{ Main phase } \\
\hline & $\mathrm{O}$ & $\mathrm{Mg}$ & $\mathrm{Al}$ & $\mathrm{Si}$ & $\mathrm{Ca}$ & $\mathrm{Ti}$ & \\
\hline A & 48.2 & 51.7 & - & - & 0.1 & - & $\mathrm{MgO}$; periclase \\
\hline B & 59.4 & 1.7 & 0.2 & 12.9 & 25.7 & - & $\mathrm{Ca}_{2} \mathrm{SiO}_{4}$; dicalcium silicate \\
\hline $\mathrm{C}$ & 58.9 & 10.7 & 0.2 & 10.4 & 19.7 & - & $\mathrm{Ca}_{2} \mathrm{SiO}_{4}$; dicalcium silicate \\
\hline $\mathrm{D}$ & 47.4 & 52.7 & - & - & - & - & $\mathrm{MgO}$; periclase \\
\hline $\mathrm{E}$ & 55.9 & 28.9 & 0.8 & - & - & 14.3 & $\mathrm{Mg}_{2} \mathrm{TiO}_{4} ;$ qandilite \\
\hline $\mathrm{F}$ & 59.9 & 1.5 & - & - & 18.8 & 19.8 & $\mathrm{CaTiO}_{3}$; perovskite \\
\hline G & 59.8 & 0.4 & - & - & 19.8 & 19.9 & $\mathrm{CaTiO}_{3}$; perovskite \\
\hline $\mathrm{H}$ & 58.7 & 20.9 & - & - & 0.1 & 20.3 & $\mathrm{MgTiO}_{3} ;$ geikielite \\
\hline I & 55.9 & 29.1 & 0.8 & - & - & 14.2 & $\mathrm{Mg}_{2} \mathrm{TiO}_{4} ;$ qandilite \\
\hline
\end{tabular}


Fig. 10 Samples of T1 material after the corrosion test

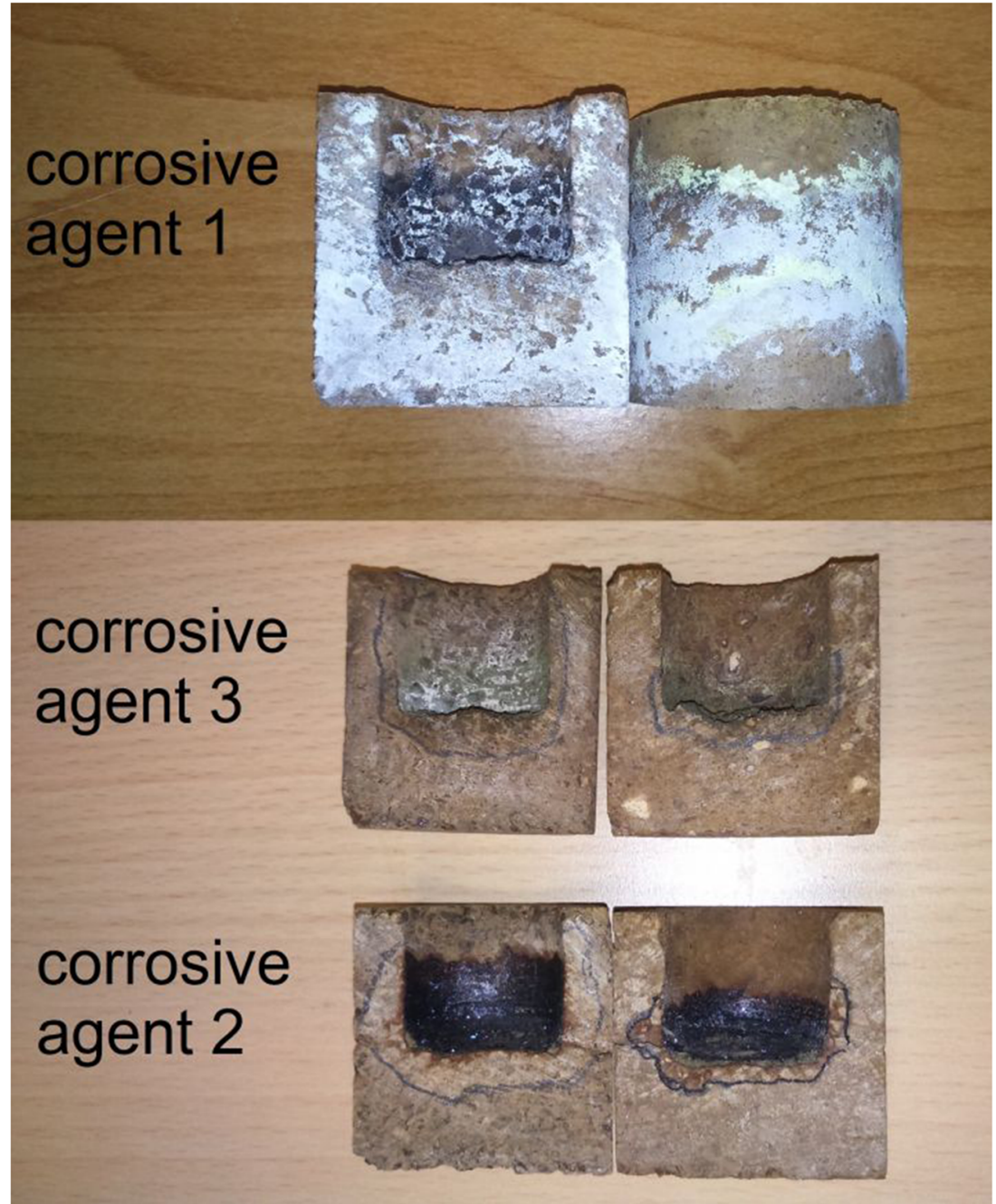

- A higher content of titania (more than $10 \%$ ) causes considerable deterioration of $\mathrm{MgO}-\mathrm{TiO}_{2}$ refractories' properties, in particular with regard to open porosity, mechanical strength and gaseous permeability, which is caused by the formation of an unfavourable microstructure with disappearance of the granular character of the matrix of
Fig. 11 Correlation between corrosion resistance and the type of refractory samples obtained

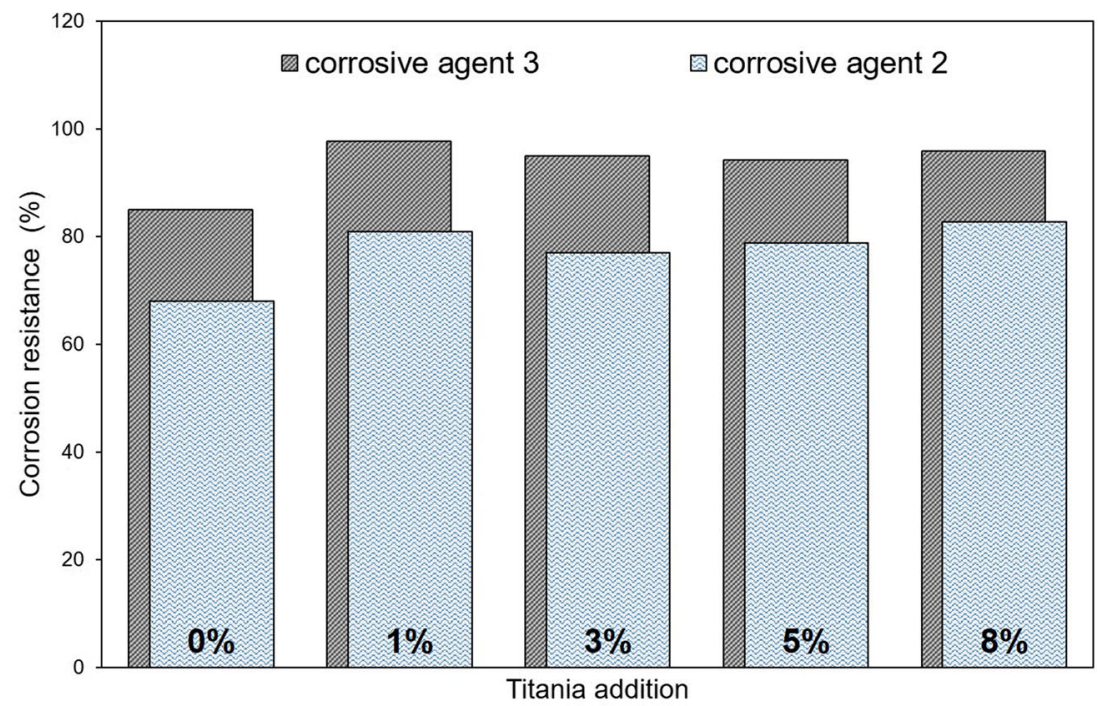


refractories and the simultaneous formation of passthrough pores.

- Titania addition improves materials' corrosive resistance, although the researchers did not find any correlation with the amount of titanium oxide added to the system.

Acknowledgements This work is the result of a statutory activity at the Institute of Ceramics and Building Materials, Refractory Materials Division in Gliwice supported by the Polish Ministry of Science and Higher Education.

Open Access This article is licensed under a Creative Commons Attribution 4.0 International License, which permits use, sharing, adaptation, distribution and reproduction in any medium or format, as long as you give appropriate credit to the original author(s) and the source, provide a link to the Creative Commons licence, and indicate if changes were made. The images or other third party material in this article are included in the article's Creative Commons licence, unless indicated otherwise in a credit line to the material. If material is not included in the article's Creative Commons licence and your intended use is not permitted by statutory regulation or exceeds the permitted use, you will need to obtain permission directly from the copyright holder. To view a copy of this licence, visit http://creativecommons.org/licenses/by/4.0/.

\section{References}

1. Szczerba, J.: Modified magnesia refractory materials. Ceramics. 99, 1-204 (2007) (in Polish)

2. Routschka, G. (ed.): Refractory Materials - Pocket Manual, 2nd edn. Vulkan-Verlag, Essen (2004)

3. Pawłowski S., Serkowski S.: Materiały ogniotrwałe - własności i zastosowanie w urządzeniach przemysłowych. Tom 1, Wyd. SITPH, Gliwice 1996.

4. Nadachowski, F. (ed.): Draft of the Refractory Material Technology, 2nd edn. Silesian Technical Publishing, Katowice (1995) (in Polish)

5. Othman, A.G.M., Khalil, N.M.: Sintering of magnesia refractories through the formation of periclase-forsterite-spinel phases. Ceram. Int. 31, 1117-1121 (2005)

6. Garbers-Craig, A.M.: Presidential address: How cool are refractory materials? J. South. Afr. Inst. Min. Metall. 108, 491-506 (2008)

7. Sadik, C., Manni, A., El Kalakhi, S., El Amrani El Hassani, I.: Preparation and characterization of possible basic ceramics from Moroccan magnesite. J. Aust. Ceram. Soc. 55, 15-423 (2019)

8. IARC Working Group on the evaluation of carcinogenic risks to humans. A Review of Human Carcinogens. Part C: Arsenic, Metals, Fibres, and Dusts, IARC, Lyon, 2009.

9. Kusiorowski, R., Wojsa, J., Psiuk, B., Wala, T.: Influence of zirconia addition on the properties of magnesia refractories. Ceram. Int. 42, 11373-11386 (2016)

10. Kusiorowski, R., Psiuk, B.: Fused magnesia-zirconia co-clinker for fired refractories. Ceram. Int. 43, 14263-14270 (2017)

11. Jedynak, L., Wojsa, J., Podwórny, J., Wala, T.: Refractories from the $\mathrm{MgO}-\mathrm{Al}_{2} \mathrm{O}_{3}-\mathrm{SnO}_{2}$ system for metallurgical applications. Materiały Ceramiczne/Ceramic Materials. 63, 34-39 (2011)

12. Yadav, H.M., Kim, J., Pawar, S.H.: Developments in photocatalytic antibacterial activity of nano $\mathrm{TiO}_{2}$ : a review. Korean J. Chem. Eng. 33, 1989-1998 (2016)

13. Bayal, N., Jeevanandam, P.: Synthesis of $\mathrm{TiO} 2-\mathrm{MgO}$ mixed metal oxide nanoparticles via a sol-gel method and studies on their optical properties. Ceram. Int. 40, 15463-15477 (2014)
14. Zhang, Y., Jiang, Z., Huang, J., Lim, L.Y., Li, W., Deng, J., Gong, D., Tang, Y., Lai, Y., Chen, Z.: Titanate and titania nanostructured materials for environmental and energy applications: a review. RSC Adv. 5, 79479-79510 (2015)

15. Maitra, S., Das, S., Sen, A.: The role of $\mathrm{TiO}_{2}$ in the densification of low cement $\mathrm{Al}_{2} \mathrm{O}_{3}-\mathrm{MgO}$ spinel castable. Ceram. Int. 33, 239-243 (2007)

16. Mohajer, A.S., Ghanbarnezhad, S., Sharifi, L., Mirhosseini, S.H., Irvani, Y.M.: The effect of $\mathrm{TiO}_{2}$ on sinterability and the formation of spinels phases on $\mathrm{MgO}-\mathrm{Al}_{2} \mathrm{O}_{3}-\mathrm{TiO}_{2}$ systems. Int. J. Res. Sci. Manag. 1, 13-20 (2014)

17. Yuan, W.J., Deng, C.J., Zhu, H.X.: Effect of $\mathrm{TiO}_{2}$ addition on the expansion behaviour of alumina-magnesia refractory castables. Mater. Chem. Phys. 162, 724-733 (2015)

18. Suzuki, Y., Shinoda, Y.: Magnesium dititanate $\left(\mathrm{MgTi}_{2} \mathrm{O}_{5}\right)$ with pseudobrookite structure: a review. Sci. Technol. Adv. Mater. 12, 034301 (2011) 6pp

19. Xie, X., Lu, G., Du, W., Wang, Y., Yu, J.: Effect of TiO ${ }_{2}$ on melting and crystallization mechanism of fused magnesia. Asian J. Chem. 27, 1823-1827 (2015)

20. Lee, Y.B., Park, H.C., Oh, K.D., Riley, F.L.: Sintering and microstructure development in the system $\mathrm{MgO}-\mathrm{TiO}_{2}$. J. Mater. Sci. 33, 4321-4325 (1998)

21. Chaudhuri, M., Banerjee, G., Kumar, A., Sarkar, S.L.: Secondary phases in natural magnesite sintered with addition of titanium ilmenite and zirconia. J. Mater. Sci. 34, 5821-5825 (1999)

22. Ghanbarnezhad, S., Nemati, A., Bavand-Vandchali, M., Naghizadeh, R.: Effect of $\mathrm{TiO}_{2}$ in spinel formation and reactive sintering of magnesia-rich ceramics. Int. J. Eng. Adv. Technol. 2, 85-87 (2013)

23. Kalpakli, Y.K.: Investigation of $\mathrm{TiO}_{2}$-added refractory brick properties from calcined magnesite raw material. Refract. Ind. Ceram. 49, 314-318 (2008)

24. Manivasakan, P., Rajendran, V., Rauta, P.R., Sahu, B.B., Sahu, P., Panda, B.K., Valiyaveettill, S., Jegadesan, S.: Effect of $\mathrm{TiO}_{2}$ nanoparticles on properties of silica refractory. J. Am. Ceram. Soc. 93, 2236-2243 (2010)

25. Rodríguez, E., Moreno, F.H., Aguilar-Martínez, J.A., MontesMejía, A.E., Ruiz-Valdés, J.J., Puente-Ornelas, R., Contreras, J.E.: Effect of nano-titania content on the mechano-physical properties of magnesia refractory composite. Ceram. Int. 42, 8445-8452 (2016)

26. Mulange D.M., Garbers-Craig A.: Effects of $\mathrm{TiO}_{2}$ addition to chrome-magnesia brick on its mechanical and thermosmechanical properties, as well as its matte penetration and slag corrosion resistance, Proceeding 347 of Unitecr 2015.

27. Jastrzębska, I., Szczerba, J., Prorok, R., Śnieżek, E.: An experimental study on hydration of various magnesia raw materials. CeramicsSilikaty. 59, 48-58 (2015)

28. Zhou, M.F., Bak, T., Nowotny, J., Rekas, M., Sorrell, C.C., Vance, E.R.: Defect chemistry and semiconducting properties of calcium titanate. J. Mater. Sci. Mater. Electron. 13, 697-704 (2002)

29. Sembiring, S., Riyanto, A., Rumiyanti, L., Sembiring, Z., Situmeang, R.: Effect of sintering temperature on the structural and physical properties of forsterite using amorphous rice husk silica as refractory precursors. J. Aust. Ceram. Soc. (2019). https://doi.org/10.1007/s41779-019-00346-2

30. Jantzen, T., Hack, K., Yazhenskikh, E., Müller, M.: Addition of $\mathrm{TiO}_{2}$ and $\mathrm{Ti}_{2} \mathrm{O}_{3}$ to the $\mathrm{Al}_{2} \mathrm{O}_{3}-\mathrm{FeO}-\mathrm{Fe}_{2} \mathrm{O}_{3}-\mathrm{MgO}$ system. Calphad. 62, 187-200 (2018)

Publisher's note Springer Nature remains neutral with regard to jurisdictional claims in published maps and institutional affiliations. 